\title{
CATECHOL-O-METHYLTRANSFERASE IN RAT PLACENTA, HUMAN PLACENTA AND CHORIOCARCINOMA GROWN IN CULTURE
}

\author{
G. H. GHEN, D. C. KLEIN AND J. C. ROBINSON \\ Laboratory of Biomedical Sciences, \\ National Institute of Child Health and Human Development, \\ National Institutes of Health, Bethesda, Maryland 20014, U.S.A.
}

(Received 5th February 1974)

The present report is the first in a projected series of investigations on biogenic amine-synthesizing and -degrading enzymes in trophoblast. The work is being undertaken to gain information relating to two questions. First, do the placental enzymes which degrade biogenic amines and related compounds provide an important biochemical barrier which protects the fetus against undesirable stimulation by physiological and pharmacological compounds in the maternal circulation? Secondly, do critical changes in biogenic amine metabolism in the placenta precede or accompany parturition, and might they be involved in the actual mechanism underlying the initiation of parturition?

Catechol-O-methyltransferase (COMT, E.C.2.1.1.6) is an enzyme which inactivates certain catecholamines and $\mathrm{O}$-methylates 2-hydroxyoestradiol-17 $\beta$ (Ball, Knuppen, Haupt \& Breuer, 1971); it has been purified 66-fold from human placenta (Gugler, Knuppen \& Breuer, 1970). We report COMT levels in rat placenta at various stages of gestation, in human placenta at term, and in choriocarcinoma grown in culture.

Pregnant Sprague-Dawley rats, inseminated on known dates, were obtained from the Holtzman Company, Madison, Wisconsin. Rats were killed by decapitation, and the placentae from each rat were individually pooled. The placentae were washed with cold water, blotted and weighed. They were then homogenized in 3 vols of $0.25 \mathrm{M}$-sucrose for $1 \mathrm{~min}$ in an Omnimixer (Ivan Sorvall Inc., Newton, Connecticut). Whole blood from each rat was also collected from the severed blood vessels of the neck, weighed, and homogenized in the same way as were the placentae.

After vaginal delivery at term, human placentae were obtained from local hospitals. A 10-g sample from each placenta was washed in cold water, blotted, weighed, and homogenized in 3 vols of $0.25 \mathrm{M}$-sucrose as for the rat placentae.

Human choriocarcinoma cells were grown as previously described (Edlow, Kohler \& Robinson, 1972). The cells were harvested on the 8th day. Three vols of $0.25 \mathrm{M}$-sucrose were added to the washed and weighed cells, which were then homogenized as described above.

Homogenates were centrifuged at $150,000 \mathrm{~g}$ for $2 \mathrm{hr}$, and the supernatant 
fractions were assayed for COMT. A single extraction recovered $91 \%$ of the activity from the homogenates. All steps in the preparation of the extracts were carried out at 0 to $5^{\circ} \mathrm{C}$.

The assay method of Gugler et al. (1970) was modified by substituting dithiothreitol (DTT) for cysteine as the enzyme activator. Optimal assay conditions ( $\mathrm{pH}$, concentrations of substrate, $\mathrm{MgCl}_{2}, \mathrm{DTT}$, and S-adenosylmethionine) for rat placental COMT were found to be similar to those reported by Gugler et al. (1970) for human placenta. The incubation mixture contained the following in a total of $0.25 \mathrm{ml}$ : 200 mm-potassium phosphate buffer, $\mathrm{pH} 7.7 ; 0.4$ mM- $\left[{ }^{14} \mathrm{C}\right]$ methyl-S-adenosylmethionine, $0.033 \mu \mathrm{Ci} ; 2 \mathrm{~mm}$-epinephrine bitartrate; $16 \mathrm{~mm}-\mathrm{MgCl}_{2} ; 1 \mathrm{~mm}$-DTT; and $50 \mu \mathrm{l}$ enzyme preparation. The mixture was incubated at $37^{\circ} \mathrm{C}$ for $1 \mathrm{hr}$ in a shaker bath. Epinephrine was omitted from the blank. The incubation was terminated by adding $0.4 \mathrm{ml}$ of $1 \mathrm{~m}$-sodium borate buffer, $\mathrm{pH} 10 \cdot 0$, and placing the test-tube in an ice-bath. The incubation mixture was then saturated with $\mathrm{NaCl}$. The product, metanephrine, was extracted into $1 \mathrm{ml}$ water-saturated $n$-butanol on a Vortex-Genie mixer (Scientific Industries, Inc., Springfield, Mass.). After centrifugation, $0.5 \mathrm{ml}$ of the $n$-butanol extract was placed in a scintillation vial with $15 \mathrm{ml}$ scintillation fluid and $1 \mathrm{ml}$ methanol, and the radioactivity was measured.

Table 1. Enzyme activity and other parameters in rat placenta

\begin{tabular}{|c|c|c|c|c|c|c|}
\hline \multirow{2}{*}{$\begin{array}{l}\text { Stage of } \\
\text { gestation }\end{array}$} & \multicolumn{3}{|c|}{ COMT activity } & \multicolumn{3}{|c|}{ Other parameters } \\
\hline & $\begin{array}{c}\text { Units/ } \\
\text { rat }\end{array}$ & $\begin{array}{c}\text { Units/ } \\
\text { ml extract }\end{array}$ & $\begin{array}{c}\text { Units| } \\
m g \text { protein }\end{array}$ & $\begin{array}{c}\text { Placental } \\
\text { mass }(\mathrm{g}) / \text { rat }\end{array}$ & $\begin{array}{c}\text { Extractable } \\
\text { protein }(m g) / \text { rat }\end{array}$ & $\begin{array}{c}\text { Protein }(m g) / \\
m l \text { extract }\end{array}$ \\
\hline $\begin{array}{l}\text { Day } 14 \\
\text { Day } 17 \\
\text { Day } 21\end{array}$ & $\begin{array}{r}4274 \pm 247 \\
8284 \pm 665 \\
15256 \pm 865\end{array}$ & $\begin{array}{l}724 \pm 46 \\
571 \pm 24 \\
929 \pm 15\end{array}$ & $\begin{array}{l}69 \pm 5 \cdot 0 \\
48 \pm 2 \cdot 0 \\
80 \pm 3 \cdot 8\end{array}$ & $\begin{array}{l}1 \cdot 6 \pm 0.09 \\
4 \cdot 1 \pm 0.27 \\
4 \cdot 6 \pm 0.23\end{array}$ & $\begin{array}{c}63 \pm 3 \cdot 8 \\
173 \pm 15 \cdot 6 \\
194 \pm 19.7\end{array}$ & $\begin{array}{l}11 \pm 0.1 \\
12 \pm 0.4 \\
12 \pm 0.6\end{array}$ \\
\hline
\end{tabular}

The differences in COMT activity between different days of gestation are all statistically significant $(P<0.02$, Student's $t$ test) except the difference between Day 14 and Day 21 when the activity is expressed in units $/ \mathrm{mg}$ protein. There were four rats in each group. Data are presented as means $\pm \mathrm{S}$.E.

In order to verify the identity of the reaction product extracted into $n$ butanol as metanephrine, the $n$-butanol extract was evaporated to a small volume on a Rotary Evapo-Mix evaporator (Buchler Instruments, Fort Lee, New Jersey), spotted on a precoated thin-layer chromatography cellulose plate (EM Laboratories Inc., Elmsford, N.Y.), and developed in $n$-butanol saturated with $3 \mathrm{~N}-\mathrm{HCl}$. The catecholamines were detected by spraying with a $p$-nitroaniline reagent (Potter, Vochten \& Schaepdryver, 1965). The radioactive spots were detected using a Varian Aerograph Thin Layer Scanner (Varian Co., Walnut Creek, Galifornia). The results showed that $\left[{ }^{14} \mathrm{C}\right]-$ metanephrine was the only radiochemical extracted by $n$-butanol. Using known amounts of $\left[{ }^{3} \mathrm{H}\right]$ metanephrine, it was shown that $63 \%$ of the metanephrine present was extracted into the organic phase. Enzyme activity was expressed as units ( 1 unit of enzyme produces $1 \mathrm{nmol}$ metanephrine per $\mathrm{hr}$ ) per $\mathrm{mg}$ protein, per $\mathrm{ml}$ extract, or per $\mathrm{g}$ tissue or cells. It was also expressed in terms of units per rat. The results were corrected for the $63 \%$ recovery.

The total amount of COMT activity in rat placental tissue was found to 
increase approximately fourfold during the last 7 days (Days 14 to 21) of gestation (Table 1). The increase between Days 14 and 17 was less than the increase in protein and in total placental mass during this period, resulting in approximately a $30 \%$ decrease in specific activity. During the last 4 days of gestation, the increase in enzyme activity was about twofold whereas the increase in total placental mass and protein was negligible during this time. This caused a marked increase in the specific activity of COMT. The greater increase in COMT activity during the last 4 days of gestation compared with the increase in placental mass and total protein suggests that a mechanism may exist which specifically increases the activity of COMT, either by increased production, decreased degradation, or stabilization of the enzyme.

In a separate experiment designed to test the possibility that the increase in COMT activity observed between Days 17 and 21 occurred abruptly immediately before birth, placentae were assayed on Day 20 and at the time of birth (which occurred on Days 21 and 22). The COMT activity (mean \pm S.E.) on Day 20 was $3103 \pm 90$ units/g tissue and $66 \pm 1.5$ units/mg protein; the values at the time of birth were, respectively, $3125 \pm 114$ and $60 \pm 4 \cdot 1$. Thus, there was no significant difference in enzyme activity on the 2 days.

Table 2. Human placental COMT activity at term and in choriocarcinoma cells

\begin{tabular}{l|c|c|c}
\hline & No. of samples & \multicolumn{2}{|c|}{ COMT activity (mean \pm S.E.) } \\
\cline { 2 - 3 } & $\begin{array}{c}\text { Units/g tissue } \\
\text { or cell }\end{array}$ & Units/mg protein \\
\hline $\begin{array}{l}\text { Euman placenta at term } \\
\begin{array}{l}\text { Choriocarcinoma cells } \\
\text { Choriocarcinoma cells } \\
\text { grown in 0.01 mM- } \\
\text { epinephrine }\end{array}\end{array}$ & 6 & $\begin{array}{c}1071 \pm 62 \cdot 3 \\
26 \pm 1 \cdot 3\end{array}$ & $\begin{array}{r}48 \pm 9.9 \\
2 \pm 0.2\end{array}$ \\
\hline
\end{tabular}

To test whether blood entrapped in the placenta contributed substantially to the measured COMT activity (Cohn, Dunner \& Axelrod, 1970), the enzyme was assayed in whole blood. On a weight basis, the COMT activity in whole blood was only about 1 to $3 \%$ of the activity in the placenta.

The COMT activity of human placenta at term was about one third or a half that of rat placenta at term, depending on the manner in which it was expressed (Table 2).

The COMT activity in choriocarcinoma cells was found to be much less than in human placenta at term (Table 2). To determine whether COMT activity could be induced by epinephrine, choriocarcinoma cells were cultured in a medium containing $0.01 \mathrm{~mm}$ - or $1 \mathrm{~mm}$-epinephrine and the medium was changed three times during the 8-day culture period. In the presence of $0.01 \mathrm{~mm}$-epinephrine, COMT showed no increase above the values of control cells. In the presence of $1 \mathrm{~mm}$-epinephrine, a sufficient number of cells for assay could not be harvested. No COMT assay was made in this case.

These experiments show that COMT activity is present in rat placenta as soon as the placenta becomes grossly recognizable and that the rate of increase 
in COMT activity rises in the last part of gestation. This enhanced activity might result in increased local inactivation of catecholamines and oestrogens, which are known to affect the uterus in pregnancy, but no remarkable alterations in COMT activity occurred at term in the rat. This finding lends no support to the possibility that such changes play a causative rôle in initiating parturition.

\section{REFERENCES}

Ball, P., KNuppen, R., Haupt, M. \& Breuer, H. (1971) Kinetic properties of a soluble catechol-Omethyltransferase of human liver. Eur. 7. Biochem. 26, 560.

Cohn, C. K., Dunner, D. L. \& Axelrod, J. (1970) Reduced catechol-O-methyltransferase activity in red blood cells of women with primary affective disorder. Science, $\mathcal{N} . Y .170,1323$.

Edlow, J. B., Kohler, P. O. \& Robinson, J. G. (1972) Choriocarcinoma in vitro: evidence for exchange of enzymes between culture medium and cells. Proc. Soc. exp. Biol. Med. 141, 798.

Gugler, R., KNuppen, R. \& BReuer, H. (1970) Reinigung und Charakterisierung einer S-Adenosylmethionin: Catechol-O-Methyltransferase der menschlichen Placenta. Biochim. biophys. Acta, $220,10$.

Potter, W. P. DE, Vochten, R. F. \& Schaepdryver, A. F. de (1965) Thin layer chromatography of catecholamines and their metabolites. Experientia, 21, 482. 